\title{
$35(2) \cdot 2021$
}

ISSN 2080-1653

DOI 10.24917/20801653.352.8

\section{MATEUSZ ĆWIKŁA}

Akademia Humanistyczno-Ekonomiczna w Łodzi, Polska

University of Humanities and Economics in Lodz, Poland

\section{Podejmowanie działalności gospodarczej w ramach naborów LGD "Beskid Gorlicki" w kontekście przemian strukturalnych w obszarze przemysłu i usług}

\section{Starting a business as part of the LAG „Beskid Gorlicki" recruitment in the context of structural changes in the area of industry and services}

\begin{abstract}
Streszczenie: W powiecie gorlickim w ostatnich latach osoby podejmujące działalność gospodarczą mogły skorzystać z kilku różnych inicjatyw wsparcia, które były dotowane z funduszy Unii Europejskiej. Do tych projektów należy m.in. podejmowanie działalności gospodarczej w ramach Programu Rozwoju Obszarów Wiejskich na lata 2014-2020, prowadzone przez Lokalną Grupę Działania „Beskid Gorlicki”. Celem opracowania jest charakterystyka funduszy UE przeznaczonych na podejmowanie działalności gospodarczej w ramach Programu Rozwoju Obszarów Wiejskich na lata 2014-2020, prowadzonego przez LGD „Beskid Gorlicki”. Przedmiotem opracowania jest również analiza istniejących tendencji w kontekście uwarunkowań strukturalnych, w oparciu o Polską Klasyfikację Działalności (PKD). W latach 2017-2019 LGD „Beskid Gorlicki” przeprowadziła kilka naborów w ramach podejmowania działalności gospodarczej. Ogółem na 97 złożonych wniosków pozytywnie rozpatrzono 62 z nich, co stanowiło $64 \%$ operacji mieszczących się w limicie dostępnych środków. Łącznie w ramach czterech naborów wydatkowane zostało 3,72 mln zł. Najwięcej dofinansowań otrzymały podmioty zaliczane do sekcji F - budownictwo (720 tys. zł, co stanowi ogółem 19,4\% całej wydatkowanej kwoty w analizowanym okresie) oraz sekcji C - przetwórstwo przemysłowe (660 tys. zł, ogółem 17,7\%). Stosunkowo duży odsetek przyznanych dotacji (po 14,5\%) w kwocie po 540 tys. zł przypadł sekcjom M - działalność profesjonalna, naukowa i techniczna i S - pozostała działalność usługowa.
\end{abstract}

\footnotetext{
Abstract: In the Gorlice poviat (Poland), in recent years, people starting a business activity could take advantage of several different support initiatives that were co-financed from European Union funds. These projects include undertaking business activity under the Rural Development Program for 2014-2020, run by LAG "Beskid Gorlicki". The aim of the study is to describe the EU funds for undertaking business activities under the Rural Development Program for 2014-2020, run by the LAG "Beskid Gorlicki". The subject of the study was also the analysis of the existing trends in the context of structural conditions, based on the Polish Classification of Activities (PKD). In 2017-2019, the LAG "Beskid Gorlicki" conducted several recruitments as
} 
part of starting a business. In total, out of 97 submitted applications, 62 of them were approved, which constituted $64 \%$ of operations within the limit of available funds. A total of PLN 3.72 million was spent under four calls for proposals. The largest number of subsidies was granted to entities included in section $\mathrm{F}$ - construction (PLN 720,000, which constitutes a total of 19.4\% of the total amount spent in the analyzed period) and section C - industrial processing (PLN 660,000, in total 17.7\%). A relatively large percentage of granted subsidies (14.5\% each) in the amount of PLN 540,000 each went to sections M - professional, scientific and technical activities and $\mathrm{S}$ - other service activities. Słowa kluczowe: fundusze europejskie; LGD „Beskid Gorlicki”; podejmowanie działalności gospodarczej.
Keywords: European funds; LAG „Beskid Gorlicki”; undertaking business activity.

Otrzymano: 11 stycznia 2021

Received: 11 January 2021

Zaakceptowano: 8 marca 2021

Accepted: 8 March 2021

Sugerowana cytacja / Suggested citation:

Ćwikła, M. (2021). Podejmowanie działalności gospodarczej w ramach naborów LGD „Beskid Gorlicki” w kontekście przemian strukturalnych w obszarze przemysłu i usług. Prace Komisji Geografii Przemysłu Polskiego Towarzystwa Geograficznego, 35(2), 119-133. doi: 10.24917/20801653.352.8

\section{WSTĘP}

Współcześnie zachodzące zjawiska rozwojowe wskazują na wzrost alternatywnych kierunków ewolucji obszarów wiejskich, coraz częściej niezwiązanych z rolnictwem. Takie podejście w zakresie realizowanych przedsięwzięć stwarza szansę rozwoju ekonomicznego obszarów wiejskich. Stąd też postrzeganie ich jedynie od strony funkcji rolniczej powinno zdecydowanie zmieniać się w kierunku uwzględniającym możliwość zróżnicowania gospodarki wiejskiej. W ostatnich latach zauważa się trend wzrostowy w tym zakresie. Podstawowym filarem koncepcji rozwoju lokalnego obszarów wiejskich musi być zatem polityka równorzędnego rozwoju sektora pozarolniczego i rolniczego na wsi (Chmieliński, 2015).

W powiecie gorlickim osoby podejmujące działalność gospodarczą mogły w ostatnich latach skorzystać z kilku różnych inicjatyw wsparcia, które były dotowane z funduszy Unii Europejskiej. Lokalna Grupa Działania „Beskid Gorlicki” od kilku lat prowadzi m.in. nabory na podejmowanie działalności gospodarczej w ramach Programu Rozwoju Obszarów Wiejskich na lata 2014-2020 (PROW 2014-2020), działanie 19: Wsparcie dla rozwoju lokalnego w ramach inicjatywy LEADER, poddziałanie 19.2: Wsparcie na wdrażanie operacji w ramach strategii rozwoju lokalnego kierowanego przez społeczność. PROW 2014-2020 został opracowywany na podstawie przepisów Unii Europejskiej, w szczególności Rozporządzenia Parlamentu Europejskiego i Rady (UE) nr 1305/2013 z dnia 17 grudnia 2013 roku w sprawie wsparcia rozwoju obszarów wiejskich przez Europejski Fundusz Rolny na rzecz Rozwoju Obszarów Wiejskich (EFRROW). Kryteria wyboru operacji w ramach podejmowania działalności gospodarczej określają wymagania przygotowane przy szerokim udziale społeczności lokalnej w Lokalnej Strategii Rozwoju (LSR). Dokument ten został zatwierdzony przez Walne Zebranie Członków LGD, a jego cele szczegółowe oraz przedsięwzięcia zintegrowane były z celami przekrojowymi PROW na lata 2014-2020, w szczególności dotyczącymi innowacyjności, zmian klimatu oraz ochrony środowiska. W ramach prowadzonych naborów można było pozyskać dofinansowanie w wysokości 60 tys. zł na pojedynczą 
operację, stąd też było to jedno z najwyższych dofinansowań w Polsce na realizację tego typu działań (LGD „Beskid Gorlicki”, 2020, 7 listopada).

Zasadniczym celem PROW 2014-2020 miała być poprawa konkurencyjności rolnictwa, zrównoważone zarządzanie zasobami naturalnymi i działania w dziedzinie klimatu oraz zrównoważony rozwój terytorialny obszarów wiejskich. Cel ten obejmował kilka priorytetów i osiągany miał być poprzez realizację m.in. takich działań jak: zwiększenie włączenia społecznego, ograniczenie ubóstwa i promowanie rozwoju gospodarczego na obszarach wiejskich, ułatwienie transferu wiedzy i innowacji na obszarach wiejskich, poprawę konkurencyjności wszystkich rodzajów gospodarki rolnej i zwiększenie rentowności gospodarstw rolnych (Sługocki, 2018).

Celem opracowania jest charakterystyka funduszy UE na podejmowanie działalności gospodarczej w ramach PROW na lata 2014-2020, prowadzonego przez LGD „Beskid Gorlicki”. Przedmiotem opracowania była również analiza istniejących tendencji w kontekście uwarunkowań strukturalnych, w oparciu o Polską Klasyfikację Działalności (PKD). W związku z tym, operacjom realizowanym w ramach naboru wniosków przypisano odpowiadający im stosowny kod PKD zgodnie z Rozporządzeniem Rady Ministrów z dnia 24 grudnia 2007 roku w sprawie Polskiej Klasyfikacji Działalności (PKD) (Dz.U. 2007, nr 251, poz. 1885).

Głównym źródłem danych była ogólnodostępna dokumentacja konkursowa na stronie www.lgdbeskidgorlicki.pl oraz dane statystyczne ze strony Głównego Urzędu Statystycznego (GUS, 2020).

W opracowaniu zastosowano metodę badawczą w postaci analizy przypadku (case study) zaistniałych zjawisk, w związku z wykorzystaniem funduszy UE na rozpoczęcie działalności gospodarczej w powiecie gorlickim w ramach projektów organizowanych przez LGD „Beskid Gorlicki”. W badaniach oprócz metod jakościowych, wykorzystywanych jako podstawowy element case study, uwzględniono również metody ilościowe, co stanowi dodatkową korzyść i powinno wpłynąć pozytywnie na przedmiot analiz. W zakresie podejmowanej tematyki istotne było bazowanie na celowym doborze próby, na który wpływ miał czas lub zasoby (Pizło, 2009).

\section{STRATEGIA ROZWOJU LOKALNEGO KIEROWANEGO PRZEZ SPOŁECZNOŚĆ W POWIECIE GORLICKIM}

Powiat gorlicki znajduje się w południowo-wschodniej części województwa małopolskiego, zajmuje powierzchnię 966 km² z ludnością na poziomie 109104 mieszkańców i gęstością zaludnienia 113 osób/ $\mathrm{km}^{2}$. Pod względem takich wskaźników jak: ludność na $1 \mathrm{~km}^{2}$ czy saldo migracji na 1000 mieszkańców, powiat gorlicki klasyfikowany jest na 19. miejscu spośród wszystkich 22 powiatów w województwie małopolskim. Jedno z ostatnich miejsc - 20. odnotowuje ta jednostka samorządu terytorialnego w przypadku ilości podmiotów gospodarki narodowej w rejestrze REGON na 10 tys. ludności. Z kolei powiat gorlicki uzyskuje wysokie pozycje na tle pozostałych powiatów w przypadku takich wskaźników jak: ilość kobiet na 100 mężczyzn, wydatki budżetu powiatu, środki w dochodach budżetu powiatu na finansowanie i współfinansowanie programów i projektów unijnych (we wszystkich obszarach 4. miejsce wśród powiatów) oraz pod względem turystycznych obiektów noclegowych (8. miejsce) i stopy bezrobocia rejestrowanego (9. miejsce) (Urząd Statystyczny w Krakowie, 2019). 
Wg obecnej klasyfikacji NUTS, obowiązującej od 1 stycznia 2015 roku, powiat gorlicki wspólnie z miastem Nowy Sącz, powiatem nowosądeckim oraz limanowskim jest zaliczany do podregionu nowosądeckiego (NUTS 3). W skład powiatu gorlickiego wchodzi 10 gmin, w tym 1 gmina miejska (Gorlice), 2 gminy miejsko-wiejskie (Biecz, Bobowa) i 7 gmin wiejskich (Gorlice, Lipinki, Łużna, Moszczenica, Ropa, Sękowa, Uście Gorlickie).

Proces budowania partnerstwa pod nazwą Stowarzyszenie LGD „Beskid Gorlicki” rozpoczął się w roku 2005, podczas realizacji projektu „Tworzenie Lokalnej Grupy Działania i Zintegrowanej Strategii Rozwoju Obszarów Wiejskich Powiatu Gorlickiego”. LGD „Beskid Gorlicki” jest partnerstwem trójsektorowym skupiającym na dzień 17 sierpnia 2019 roku 81 członków, do których zalicza się: mieszkańców obszaru działania LGD, przedsiębiorców, organizacje pozarządowe, parafie, rolników, jednostki samorządu terytorialnego oraz ich jednostki administracyjne. LSR opracowana została przez zespół, w skład którego weszli pracownicy Biura LGD, członkowie LGD oraz ekspert zewnętrzny. W ramach LSR podejmowano szereg działań konsultacyjnych, informacyjnych i szkoleniowych w zakresie animacji społeczności lokalnej. Partycypacyjne metody konsultacji obejmowały: badania przeprowadzone wśród mieszkańców gmin, spotkania warsztatowe w każdej gminie, otwarte spotkanie projektowe dla mieszkańców gmin, zgłaszanie fiszek projektowych, ankiety internetowe, konsultacje online oraz tradycyjne spotkania konsultacyjne. Na podstawie wniosków płynących z działań partycypacyjnych związanych z opracowaniem diagnozy obszaru i ludności oraz analizy SWOT zawartej w strategii rozwoju lokalnego, przygotowane zostało zestawienie problemowe z uwzględnieniem związków przyczynowo-skutkowych. To z kolei pozwoliło na wypracowanie przedsięwzięć i celów głównych, do których zalicza się: poprawę sytuacji na lokalnym rynku pracy, poprawę atrakcyjności turystycznej obszaru, wzmocnienie kapitału społecznego i kulturowego. Zwłaszcza w pierwszym celu, w szczegółowym uzasadnieniu w zakresie wspierania lokalnego rozwoju na obszarach wiejskich uwzględniono zakładanie działalności gospodarczej i rozwój przedsiębiorczości oraz dywersyfikację źródeł dochodu (LGD „Beskid Gorlicki”, 2020, 7 listopada).

Fundusze strukturalne są instrumentem, który z założenia w głównej mierze ma doprowadzić do wyrównywania poziomu rozwoju poszczególnych regionów. Za pomocą różnorakich działań zapisanych w projektach można pobudzić rynek pracy i osiągnąć pożądane rezultaty. Jednym z takich działań są bezzwrotne dotacje na rozpoczęcie działalności gospodarczej, które od wielu już lat są stosowane w ramach aktywizacji zawodowej bezrobotnych. Stanowią one bardzo efektywny sposób na tworzenie miejsc pracy, lecz jednocześnie przy jego stosowaniu należy w rozsądny sposób je wykorzystywać. W szczególności należy dołożyć wszelkich starań, aby dobór osób uwzględniał ich predyspozycje przedsiębiorcze. Powinny one cechować się dużym poziomem motywacji oraz wiedzy z zakresu funkcjonowania firmy i mechanizmów rządzących rynkiem. Z kolei mentorzy, zaangażowani w prace szkoleniowo-doradcze, muszą posiadać doświadczenie i uznanie reprezentowanej branży oraz przygotowanie na wysokim poziomie merytorycznym (Brzychcy, 2013).

Przy konkursach na podejmowanie działalności gospodarczej, realizowanych przez LGD „Beskid Gorlicki”, opierano się na wymogach Rozporządzenia Ministra Rolnictwa i Rozwoju Wsi z dnia 24 września 2015 r. w sprawie szczegółowych warunków $i$ trybu przyznawania pomocy finansowej $w$ ramach poddziałania "Wsparcie na wdrażanie operacji $w$ ramach strategii rozwoju lokalnego kierowanego przez społeczność" 
objętego Programem Rozwoju Obszarów Wiejskich na lata 2014-2020 (Dz.U. 2015, poz. 1570, z późn. zm.). PROW 2014-2020 został opracowywany na podstawie przepisów Unii Europejskiej, w szczególności Rozporzq̨dzenia Parlamentu Europejskiego i Rady (UE) nr 1305/2013 z dnia 17 grudnia 2013 r. w sprawie wsparcia rozwoju obszarów wiejskich przez Europejski Fundusz Rolny na rzecz Rozwoju Obszarów Wiejskich (EFRROW) i uchylającego rozporządzenie Rady (WE) nr 1698/2005 oraz aktów delegowanych i wykonawczych Komisji Europejskiej (Dz.U. UE L 347/487, poz. 487).

Procedury oceny i wyboru operacji oraz kryteria wyboru operacji przygotowane zostały w oparciu o Lokalną Strategię Rozwoju (obowiązujące wytyczne dla PROW 2014-2020). Wybierając przedsięwzięcia do dofinansowania, z jednej strony zwracano uwagę na duże prawdopodobieństwo niwelowania zdiagnozowanych problemów w regionie, a z drugiej strony - istotne były możliwości wykorzystywania mocnych stron i potencjału obszaru w celu jego zrównoważonego i trwałego rozwoju. Kryteria wyboru operacji w zakresie podejmowania działalności gospodarczej uwzględniały wiele składowych, do których należały: kwalifikacje i/lub doświadczenie wnioskodawcy, dodatkowe miejsca pracy, wsparcie grup defaworyzowanych, wpływ na ochronę środowiska lub przeciwdziałanie zmianom klimatu, innowacyjność operacji, przedmiot operacji, gotowość do realizacji operacji, wpływ operacji na rozwój turystyki, zrównoważony rozwój obszaru LSR (LGD „Beskid Gorlicki”, 2020, 7 listopada).

Praktyka pokazuje, że istnieje wiele różnorodnych czynników warunkujących realizację projektów nastawionych na transfer wiedzy, kreowanie, adaptację i absorpcję innowacji. Implementacja tych ostatnich jest złożonym i wielowątkowym procesem, który wiąże się z koniecznością osiągnięcia celów w obszarze badań i rozwoju, a w praktyce dotyczy uruchomienia pionierskich rozwiązań (lub adaptację istniejących), co znajduje swoje odzwierciedlenie w pojawiających się opracowaniach teoretycznych oraz w rosnących wdrożeniach innowacji (Goryńska-Goldmann, Wojcieszak, 2017).

Analizy wykonane w ramach LSR potwierdziły, że powiat gorlicki charakteryzuje się ponadprzeciętnie wysokim wskaźnikiem bezrobocia. W 2020 roku (stan na 30.06.2020, GUS) w powiecie gorlickim było 2838 zarejestrowanych osób bezrobotnych, z czego najwięcej w mieście Gorlice (797 osób), a najmniej w gminie Ropa (119 osób) i Moszczenica (117 osób). W porównaniu do stanu z 30 czerwca 2017 roku, w połowie 2020 roku było o 295 mniej osób bezrobotnych w powiecie. W latach 2017-2019 następował spadek osób bezrobotnych (do 2192 osób w 2019 r.), po czym w I półroczu 2020 roku nastąpił wzrost do poziomu 2838 osób. W rozróżnieniu na wiek w powiecie gorlickim zarejestrowanych było $16,7 \%$ osób bezrobotnych do 25 roku życia (stan na 30.06.2020). Największy odsetek osób młodych był wśród bezrobotnych mieszkańców gminy Bobowa $(27,3 \%)$, zaś najmniejszy wśród bezrobotnych z miasta Gorlice $(11,5 \%)$ i gminy Sękowa (12,2\%). Z kolei osoby bezrobotne po 55 roku życia stanowiły $14,9 \%$ bezrobotnych w całym powiecie. Największy odsetek stanowiły one wśród bezrobotnych zamieszkałych na terenie gminy Biecz $(17,9 \%)$ i gminy Łużna $(16,8 \%)$, zaś najmniejszy wśród bezrobotnych z gminy Moszczenica (10,3\%) (LGD „Beskid Gorlicki”, 2020, 17 listopada).

Wg stanu na dzień 30.06.2020 roku w powiecie gorlickim bezrobotni najczęściej posiadali wykształcenie policealne i średnie zawodowe (31,7\% ogółu) lub wykształcenie zasadnicze zawodowe (30,9\% ogółu). Wykształcenie wyższe posiadało $15,0 \%$ bezrobotnych, gimnazjalne i podstawowe 14,4\%, zaś wykształcenie średnie 
ogólnokształcące posiadało 8,0\% ogółu bezrobotnych. Bezrobotni ze stażem pracy do 1 roku stanowili aż 33,0\% ogółu zarejestrowanych osób. W tym przypadku największy odsetek osób był wśród bezrobotnych z gminy Ropa (40,3\%), zaś najmniejszy wśród bezrobotnych z Gorlic (29,1\%) (Powiatowy Urząd Pracy w Gorlicach, 2020).

\section{PODEJMOWANIE DZIAŁALNOŚCI GOSPODARCZEJ W RAMACH NABORÓW PROWADZONYCH PRZEZ LGD „BESKID GORLICKI”}

W przypadku alokacji środków wspierających rozwój często dochodzi do trudności, co wynika najczęściej z postępowania decyzyjnego w aspekcie przestrzennego ukierunkowania interwencji. W literaturze odnotowuje się występowanie wyrównawczej oraz popularyzacyjno-dyfuzyjnej strategii postępowania. Pierwsza z nich określa nadmierne zróżnicowanie społeczno-ekonomiczne, stanowiące główną barierę rozwoju. W tym przypadku tylko skoncentrowane wsparcie obszarów o najgorszej sytuacji gospodarczej umożliwi wyrównanie zaistniałych dysproporcji. W założeniach drugiej strategii przyjmuje się, że pozytywny skutek odniesie usunięcie barier, które powodują zastój w podnoszeniu konkurencyjności i potencjałów wzrostowych wśród wszystkich jednostek terytorialnych (Mrozińska, 2017). W jednostkach samorządu terytorialnego czy w przedsiębiorstwach istnieje konieczność zachowania dyscypliny finansowej. Konsekwencją tego jest podejmowanie efektywnych działań, które umożliwią zaspokojenie rosnących potrzeb mieszkańców. Ten mechanizm wzrostu oczekiwań i efektywności podejmowanych działań powoduje, że coraz częściej sięga się po fundusze unijne, zapewniające wsparcie inwestycji i rozwój danej jednostki samorządu terytorialnego czy firmy (Szara, Majka, 2017).

Prowadzone przez LGD „Beskid Gorlicki” nabory wniosków w ramach PROW na lata 2014-2020 związane z przedsiębiorczością wskazywały na stale rosnące zapotrzebowanie związane głównie z tworzeniem nowych oraz rozwojem istniejących firm. Potwierdzają to dane statystyczne z naborów z ubiegłych lat, w których liczba złożonych wniosków zdecydowanie przekraczała możliwości przyznania dofinansowania przez LGD.

W 2017 roku w ramach przeprowadzonych dwóch naborów złożonych zostało ogółem 45 wniosków, z tego 30 (67\%) operacji zmieściło się w limicie środków wskazanych w ogłoszeniu o naborze (rycina 1). W 2018 roku odnotowano wysoki współczynnik przyznanych dofinansowań na rozpoczęcie działalności, na 18 złożonych wniosków przyznano 16 dofinansowań co stanowi aż 88,9\%. W kolejnym, 2019 roku, na 34 złożone wnioski, w limicie dostępnych środków znalazło się 16 podmiotów (47\%). Ogółem w latach 2017-2019 spośród wszystkich 97 wniosków wybranych do finansowania $w$ ramach naborów na podejmowanie działalności gospodarczej, tylko 62 wnioski (64\%) mieściło się w limicie dostępnych środków. Tym samym zauważa się, że w dużym stopniu nie zostały zaspokojone potrzeby społeczności lokalnej w tym zakresie (LGD „Beskid Gorlicki”, 2020, 7 listopada).

Branżami kluczowymi dla rozwoju gospodarki na terenie powiatu gorlickiego jest w głównej mierze budownictwo (ok. 30\% lokalnej gospodarki), handel hurtowy i detaliczny oraz naprawa pojazdów samochodowych (ok. 20\% lokalnej gospodarki) a także przetwórstwo przemysłowe (ok. 11\% lokalnej gospodarki) (stan na 31.12.2018, LSR). Obszar przemysłowy w mieście Gorlice, działający w ramach uregulowań specjalnej strefy ekonomicznej (korzystanie z ulg podatkowych), wpływa na rozwój 
Rycina 1. Zestawienie wszystkich wniosków zakwalifikowanych ogółem do finansowania w ramach naborów na podejmowanie działalności gospodarczej w stosunku do dofinansowanych przedsięwzięć

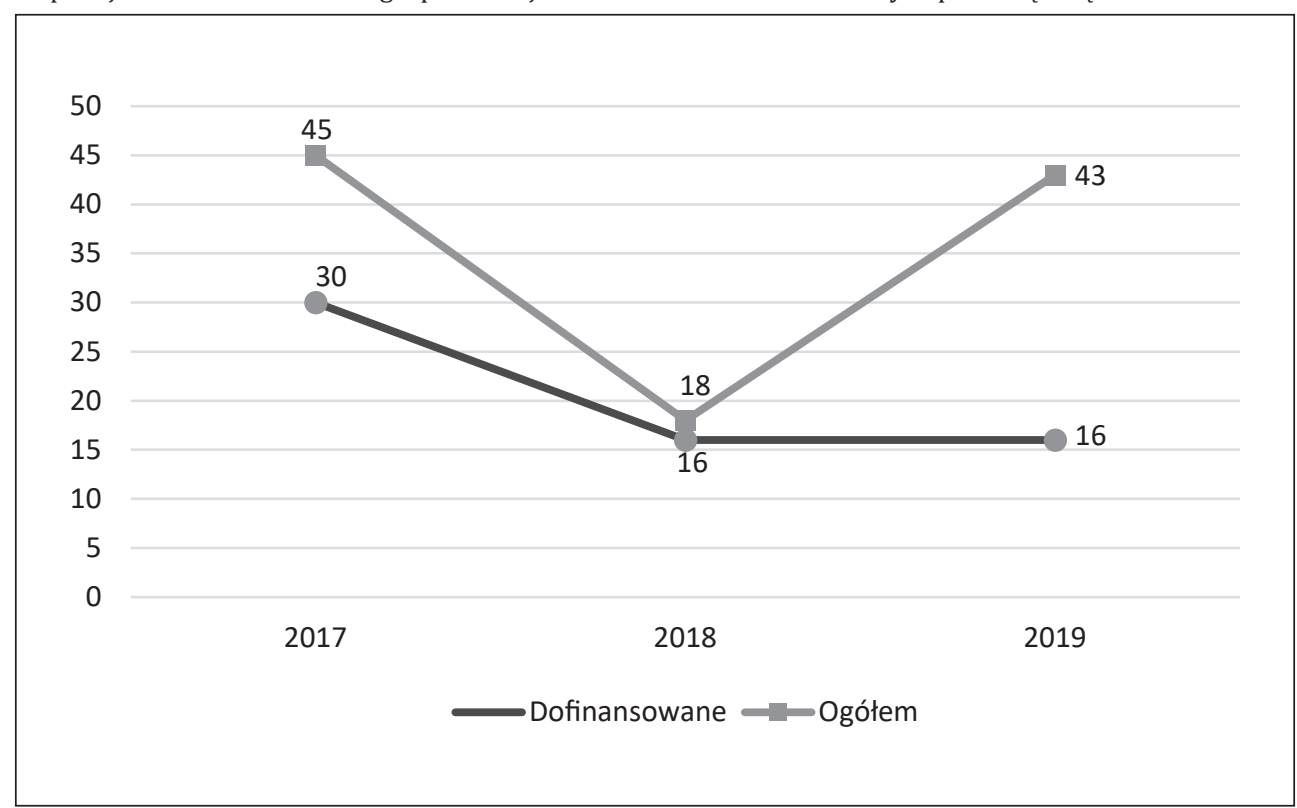

Źródło: opracowanie własne na podstawie LGD „Beskid Gorlicki” (2020, 4 grudnia)

przedsiębiorczości w szerszej skali. Istotne znaczenie w powiecie powinna mieć tworzona Strefa Aktywności Gospodarczej i Turystycznej, w ramach której zostaną przygotowane specjalne tereny inwestycyjne (LGD, 2020).

W 2017 roku 30 operacji zostało dofinansowanych środkami z „Europejskiego Funduszu Rolnego na rzecz Rozwoju Obszarów Wiejskich: Europa inwestująca w obszary wiejskie". Zdecydowana większość z nich dotyczyła, wg klasyfikacji PKD, sekcji F - budownictwo $(26,7 \%$ ) (rycina 2). Biorąc pod uwagę bardziej szczegółowe działy i grupy, były to zarówno usługi ogólnobudowlane, jak i profesje wyspecjalizowane w danej dziedzinie, takie jak: usługi brukarskie, produkcja przysłon okiennych i bram garażowych, produkcja i handel rzeźbami betonowymi i świecami parafinowymi. W drugiej najliczniej dofinansowanej grupie (po 13,3\% dofinansowania) były sekcje C - przetwórstwo przemysłowe, I - działalność związana z zakwaterowaniem i usługami gastronomicznymi oraz S - pozostała działalność usługowa. Udział dofinansowania sekcji J - informacja i komunikacja wyniósł 10\%, sekcji M - działalność profesjonalna, naukowa i techniczna oraz sekcji Q - opieka zdrowotna i pomoc społeczna po 6,7\% dofinansowanych operacji. W przypadku sekcji G - handel hurtowy i detaliczny, naprawa pojazdów samochodowych, włączając motocykle, sekcji N - działalność w zakresie usług administrowania i działalność wspierająca oraz sekcji R - działalność związana z kulturą, rozrywką i rekreacją było to po 3,3\% spośród operacji mieszczących się w limicie środków z dwóch naborów w 2017 roku. Spośród operacji, które zostały wybrane w ramach naboru wniosków, ale nie zmieściły się w limicie środków wskazanych w ogłoszeniu były po trzy operacje z sekcji F, G, M, po dwie z sekcji I i S oraz po jednej z sekcji C i J. 
Rycina 2. Zestawienie operacji w podziale na sekcje PKD, które zostały wybrane do dofinansowania w ramach prowadzonych naborów przez LGD „Beskid Gorlicki” w 2017 r.

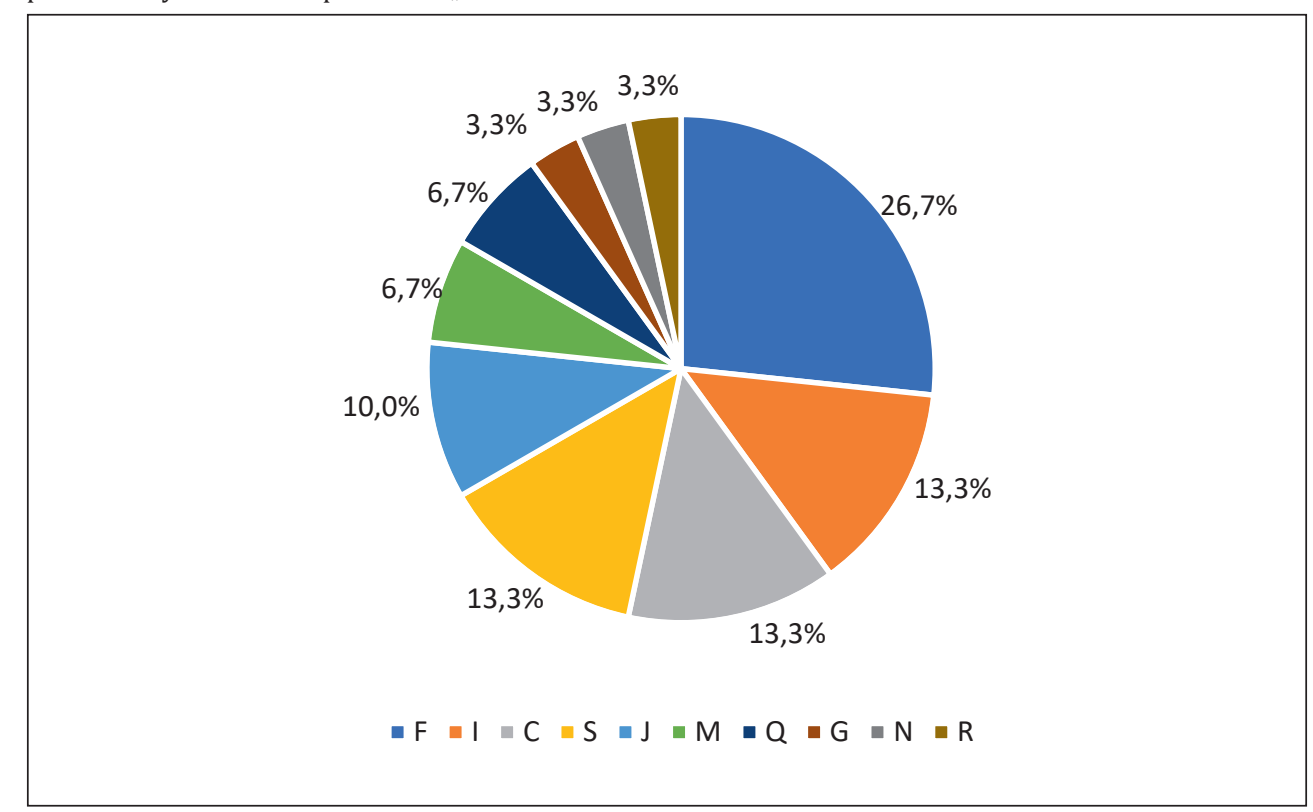

Źródło: opracowanie własne na podstawie LGD „Beskid Gorlicki” (2020, 4 grudnia)

W 2018 roku LGD „Beskid Gorlicki” przeprowadził tylko jeden nabór w zakresie podejmowania działalności gospodarczej. W jego ramach dofinansowanie uzyskało 16 operacji, z tego najwięcej, bo aż 5 wg klasyfikacji PKD dotyczyło sekcji M - 31,3\% (rycina 3). Drugą w kolejności była sekcja C (18,8\%), następnie sekcja I oraz równolegle kilka sekcji po 6,3\% udziale: F, G, N, R, S, Q. W 2018 roku w limicie środków nie zakwalifikowały się tylko dwie operacje z sekcji C i G.

W 2019 roku odbył się jeden nabór na podejmowanie działalności gospodarczej, który to charakteryzował się największym zainteresowaniem ze strony wnioskodawców. Wśród operacji mieszczących się w limicie środków najwięcej było działalności klasyfikowanych jako sekcje C i S (po 25\%), sekcja F - 18,8\%, sekcje G i M po 12,5\% oraz sekcja I - 6,3\% (rycina 4). Duża ilość wniosków niezakwalifikowanych do dofinansowania dotyczyła sekcji M (7 operacji). Spośród pozostałych, które nie podlegały dofinansowaniu odnotowano sekcje: C, F, I, Q (po dwie operacje) oraz sekcje: G, N (po jednej operacji).

Ogółem w latach 2017-2019 LGD „Beskid Gorlicki” przeprowadziła kilka naborów w ramach podejmowania działalności gospodarczej, w których łącznie wydatkowano 3,72 mln zł (LGD „Beskid Gorlicki”, 2020, 7 listopada).

Obszar przedsiębiorczości jest istotnym priorytetem w alokacji środków europejskich na rozwój konkurencyjnej gospodarki opartej na wiedzy w Polsce. Ważną grupę beneficjentów funduszy strukturalnych od początku realizacji polityki spójności w naszym kraju stanowią właśnie przedsiębiorstwa. Stosunkowo duża skala zaangażowanych środków sprawia, że efekty polityki regionalnej w obszarze przedsiębiorczości są szczególnie widoczne. Przejawem tego jest m.in. wzrost zatrudnienia, poprawa kwalifikacji pracowników, zwiększony udział pracujących w sektorze usług w gospodarce 
Rycina 3. Procentowy udział operacji w podziale na sekcje PKD, które zostały wybrane do dofinansowania w ramach prowadzonych naborów przez LGD „Beskid Gorlicki” w 2018 r.

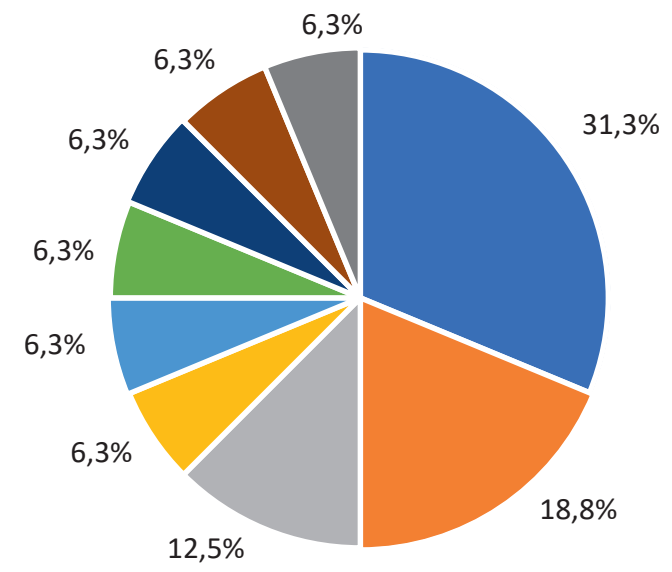

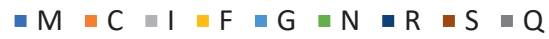

Źródło: opracowanie własne na podstawie LGD „Beskid Gorlicki” (2020, 4 grudnia)

Rycina 4. Zestawienie operacji w podziale na sekcje PKD, które zostały wybrane do dofinansowania w ramach prowadzonych naborów przez LGD „Beskid Gorlicki” w 2019 r.

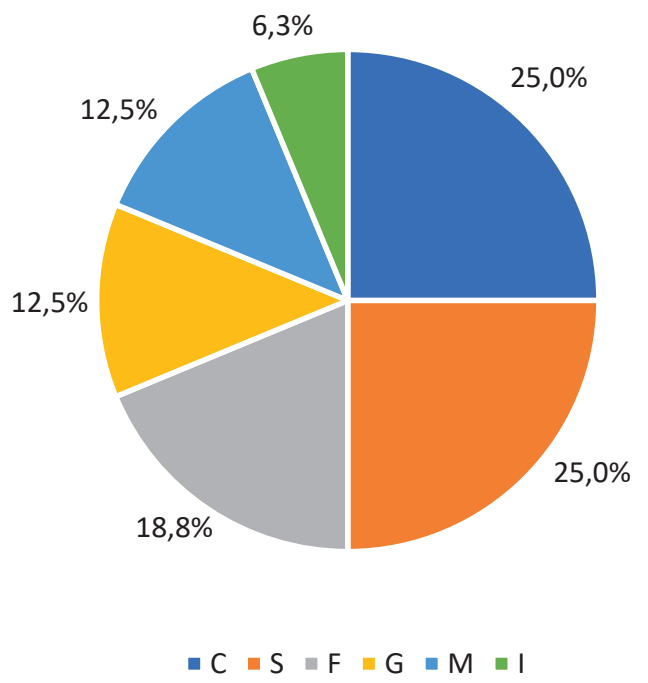

Źródło: opracowanie własne na podstawie LGD „Beskid Gorlicki” (2020, 4 grudnia) 
opartej na wiedzy. Małopolskie przedsiębiorstwa w sposób aktywny uczestniczą w realizacji polityki spójności Unii Europejskiej, są największym beneficjentem funduszy strukturalnych UE spośród podmiotów w regionie, biorąc pod uwagę zarówno liczbę realizowanych projektów, jak i ich wartość. Pozyskane środki służą realizacji wielu inwestycji, w tym podniesieniu konkurencyjności firm na rynku (Murzyn, 2013).

\section{PRZEMIANY STRUKTURALNE W OBSZARZE PRZEMYSŁU I USŁUG W POWIECIE GORLICKIM}

W procesie zmian sektorowo-przestrzennych przekształceniom ulegają też dotychczasowe struktury organizacyjne, kapitałowe, produkcyjne oraz własnościowe przedsiębiorstw, które reprezentują określone gałęzie gospodarki. Przemiany te dokonują się w określonych układach przestrzennych i wpływają na przeobrażenia bardziej złożonych struktur przestrzenno-branżowych. Tym samym funkcjonujące w danym przekroju czasowym przedsiębiorstwa i związane z nimi struktury w układzie regionalnym, reprezentują różny potencjał ekonomiczny, powstały wskutek złożonego procesu rozwojowego (technologicznego i technicznego), dokonującego się w określonym czasie. Przestrzenna lokalizacja i dotychczasowe tempo rozwoju podmiotów gospodarczych nawiązywały do zakładanych celów działalności gospodarczej, które realizowane były w określonych uwarunkowaniach, związanych z określonymi relacjami zarządzania (Zioło, 2010).

W powiecie gorlickim w 2017 roku do rejestru REGON wpisanych było łącznie 7834 podmiotów, rok później 8081, a w 2019 roku - 8482 podmiotów (rycina 5). Tym samym w ciągu trzech lat nastąpił wzrost ilości wpisanych podmiotów o 648. Sekcja F

Rycina 5. Podmioty gospodarki narodowej zarejestrowane do rejestru REGON wg sekcji PKD w powiecie gorlickim w latach 2017-2019

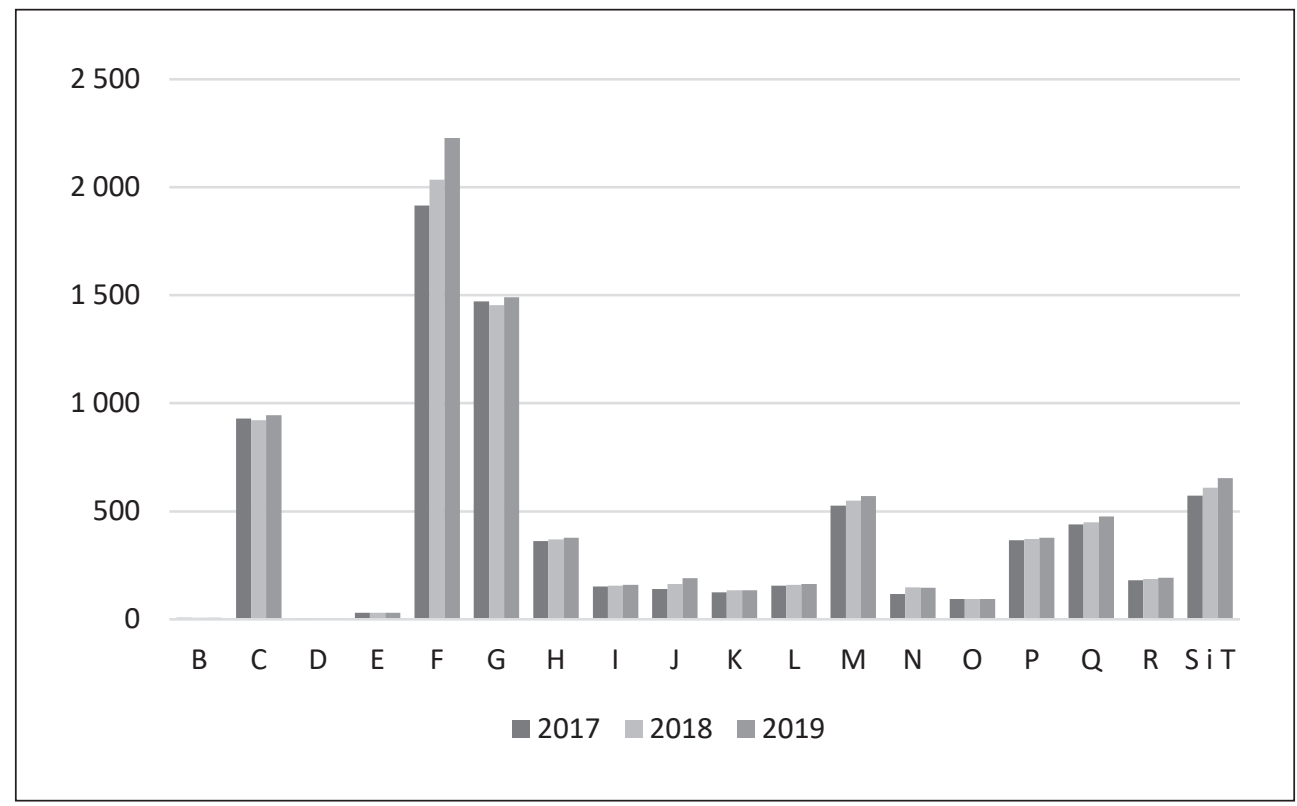

Źródło: opracowanie własne na podstawie danych GUS (2020) 
dotycząca budownictwa z liczbą 1916 podmiotów była najbardziej liczną sekcją PKD w 2017 roku, zwiększając się o dodatkową liczbę 312 w 2019 roku. Drugą największą sekcję na poziomie niespełna 1500 podmiotów stanowił handel hurtowy i detaliczny oraz naprawa pojazdów samochodowych, a trzecią najbardziej liczną sekcją było przetwórstwo przemysłowe z poziomem ok. 930 podmiotów. Spośród wszystkich sekcji PKD w latach 2017-2019 nie odnotowano zarejestrowanych podmiotów w sekcji U organizacje i zespoły eksterytorialne.

Dynamika wzrostu liczby ogółem zarejestrowanych w powiecie gorlickim podmiotów w latach 2017-2019 wyniosła 8,3\%. Systematyczny i duży przyrost dotyczył sekcji F i wynosił 16,3\%, natomiast w kolejnych dwóch najliczniejszych sekcjach był ustabilizowany i niewielki (w sekcji G - 1,3\% i w sekcji C - 1,6\%). W przeważającej większości sekcji PKD nastąpił wzrost liczby podmiotów, spadek dotyczył jedynie sekcji D (mniej o jeden podmiot) w 2019 roku względem 2017.

W latach 2017-2019 ilość nowo zarejestrowanych podmiotów w rejestrze REGON utrzymywała się na jednakowym poziomie (rycina 6). W roku 2017 było to 739 podmiotów, rok później 861 podmiotów, a w 2019 roku 847 podmiotów. Przemysł i budownictwo oscylowało w tych latach w granicach 46-50\%, rolnictwo, leśnictwo, łowiectwo i rybactwo zaledwie 1,8-2,2\%, natomiast resztę stanowiła pozostała działalność. Procentowy udział podmiotów wyrejestrowanych w ogólnej liczbie podmiotów wpisanych do rejestru REGON w latach 2017-2019 systematycznie się zmniejszał, od 9,1\% w 2017 roku do 4,7\% w 2019 roku. Ilość podmiotów wpisanych do rejestru REGON na 10 tys. ludności wzrastała i wyniosła odpowiednio: 718 w 2017 roku, 741 w 2018 i 779 w 2019. Nowo zarejestrowane podmioty gospodarki narodowej w rejestrze REGON wg sekcji PKD 2007 zostały przedstawione na rycinie 5. Wzrastające

Rycina 6. Podmioty gospodarki narodowej nowo zarejestrowane w rejestrze REGON wg sekcji PKD w powiecie gorlickim w latach 2017-2019

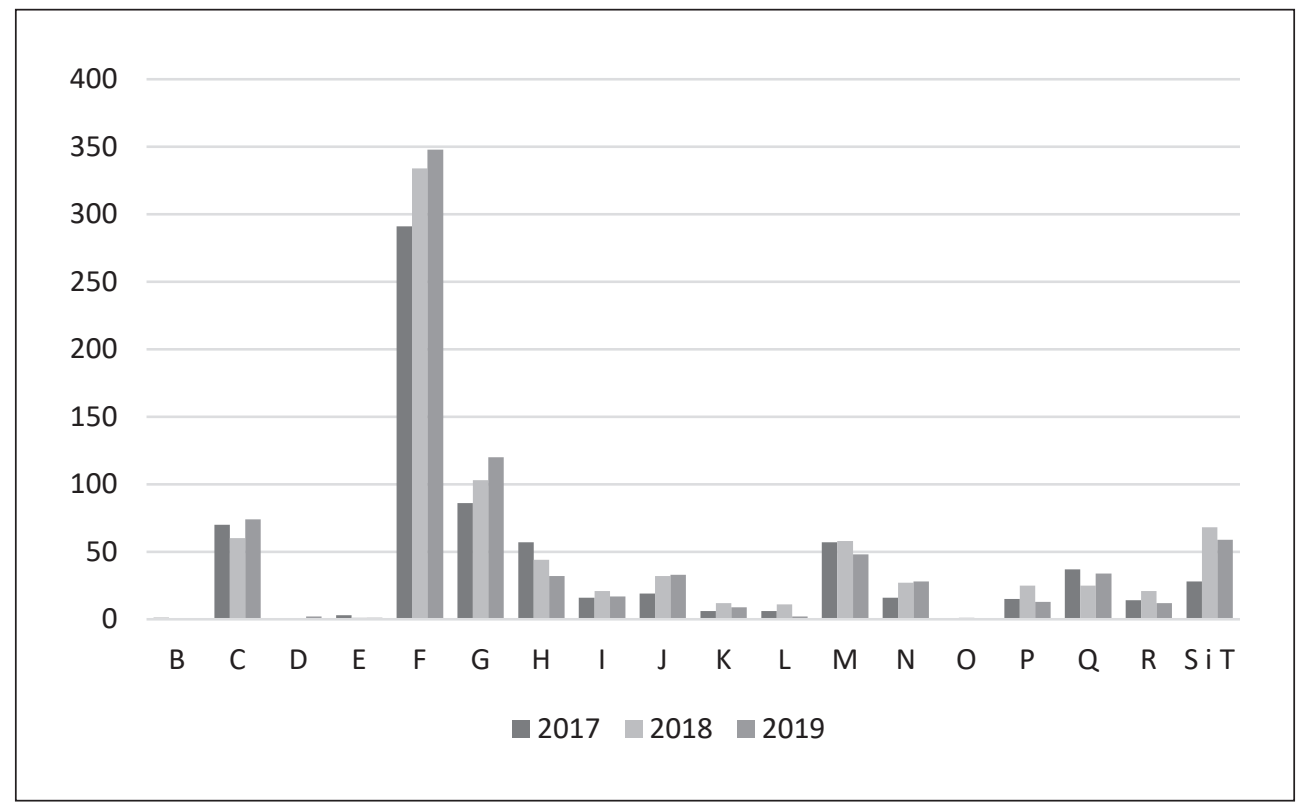

Źródło: opracowanie własne na podstawie danych GUS (2020) 
tendencje i zdecydowanie największa ilość zarejestrowanych nowych podmiotów wchodziła w skład sekcji F i było to odpowiednio 291 w 2017 roku, 334 w 2018 i 348 w 2019. Z kolei największą malejącą tendencję w rejestrowaniu nowych podmiotów odnotowano w sekcji H, z 57 w roku 2017, poprzez 44 w 2018, do 32 w 2019.

Dynamika wzrostu liczby nowo zarejestrowanych podmiotów w powiecie gorlickim w latach 2017-2019 wyniosła 14,8\%. W dominującej sekcji F przyrost liczby podmiotów względem lat 2017-2019 wyniósł 19,6\%. Większa dynamika wzrostu nastąpiła w przypadku sekcji G - 39,5\%, jednak ogólna liczba podmiotów z tej sekcji była ok. trzykrotnie niższa. Największy spadek podmiotów odnotowano w sekcji H i było to 56\% w 2019 roku względem 2017 roku.

Spośród wszystkich sekcji PKD w latach 2017-2019 nie odnotowano nowo zarejestrowanych podmiotów w sekcji U - organizacje i zespoły eksterytorialne. W przypadku sekcji B - górnictwo i wydobywanie zarejestrowany został nowy podmiot w 2017 roku, a w sekcji 0 - administracja publiczna i obrona narodowa, obowiązkowe zabezpieczenia społeczna zarejestrowano nowy podmiot dopiero w 2018 roku. W sekcji D - wytwarzanie i zaopatrywanie w energię elektryczną, gaz, parę wodną gorącą wodę i powietrze do układów klimatyzacyjnych dopiero w 2019 roku zarejestrowano dwa podmioty. Ponadto małą ilość zarejestrowanych podmiotów odnotowano w sekcji E - dostawa wody; gospodarowanie ściekami i odpadami oraz działalność związana z rekultywacją (trzy w 2017 roku, po jednym w 2018 i 2019), sekcji K - działalność finansowa i ubezpieczeniowa, odpowiednio sześć, dwanaście i dziewięć względem poszczególnych lat, a w sekcji L - działalność związana z obsługą rynku nieruchomości było odpowiednio sześć w 2017 roku, jedenaście w 2018 oraz dwa w 2019.

W latach 2017-2019 w ramach dotacji na podejmowanie działalności gospodarczej prowadzonych przez LGD „Beskid Gorlicki” najwięcej dofinansowań otrzymały podmioty zaliczane do sekcji F (720 tys. zł, co stanowi ogółem - 19,4\% całej wydatkowanej kwoty w analizowanym okresie) oraz sekcji C (660 tys. zł, ogółem 17,7\%). Stosunkowo duży odsetek przyznanych dotacji (po 14,5\%) w kwocie po 540 tys. zł przypadł sekcjom M i S.

Klasyfikacja podmiotów gospodarki narodowej w powiecie gorlickim według kryterium liczby pracujących wykazuje, że w 2019 roku zdecydowana większość tych podmiotów (8136, co stanowi aż 95,9\%) zatrudniała do 9 pracowników. W przedziale zatrudnienia $10-49$ było to 291 podmiotów (3,43\%); w przedziale $50-249$ były 53 podmioty $(0,62 \%)$, a w największym powyżej 250 pracowników jedynie 5 podmiotów (wg danych GUS). Takie statystyki świadczą o znaczącej pozycji sektora małych i średnich przedsiębiorstw (MŚP) w powiecie gorlickim. Ilość zarejestrowanych podmiotów gospodarczych ulega ciągłym przeobrażeniom wskutek zmieniających się uwarunkowań gospodarczych. Sektor MŚP wyróżnia się konkurencyjnością spośród wszystkich podmiotów gospodarczych, odgrywa największe znaczenie w rozwoju ekonomicznym Polski. Cechuje się on elastycznością i mobilnością, co stanowi o dużym potencjale gospodarczym, umożliwiającym dojście do równowagi rynkowej, ukształtowania korzystnych zjawisk w przypadku zatrudnienia oraz popytu czy wzrostu innowacyjności. Duże przedsiębiorstwa nastawione są na masową i wieloseryjną produkcję, stąd też trudniej im dostosować się do zmiennej rzeczywistości (Marcysiak, Marcysiak, 2016). 


\section{PODSUMOWANIE}

Zagadnienia dotyczące procesów zachodzących w gospodarce, w tym transformacji sektora przemysłu i usług, stanowią w dalszym ciągu jeden z ważniejszych i aktualnych problemów badawczych. Ogólne tendencje rozwoju cywilizacyjnego, uwidaczniające zmiany struktur sektorowo-przestrzennych są wyrazem różnych właściwości podmiotów gospodarczych, które cechują się rozwojem ekonomicznym, powstawaniem nowych firm, stagnacją czy recesją (Zioło, 2010). Z punktu widzenia władz publicznych konkurencyjność oznacza zdolność do tworzenia warunków dla prowadzenia działalności gospodarczej i zamieszkania zaspokajających potrzeby użytkowników (firm czy mieszkańców) danej przestrzeni (kraju, gminy). Wysiłek działania organizacji musi być ukierunkowany nie tylko na uzyskanie pozycji konkurencyjnej, ale także jej utrzymanie w długim okresie (Sługocki, 2018).

W niniejszym opracowaniu w analitycznym studium przypadku dokonano szczegółowej charakterystyki operacji na podejmowanie działalności gospodarczej w ramach naborów wniosków w latach 2017-2020, w związku z wdrażaniem Strategii Rozwoju Lokalnego, kierowanej przez społeczność Stowarzyszenia LGD „Beskid Gorlicki”.

Skuteczność pozyskiwania środków unijnych w ramach opisywanego projektu była stosunkowo wysoka i wynosiła ok. 64\%. Potencjalnie większa świadomość i rozpoznanie $\mathrm{w}$ możliwościach pozyskania dofinansowania $\mathrm{w}$ połączeniu $\mathrm{z}$ poziomem przedsiębiorczości i kondycją finansową przedsiębiorstw oraz zamożnością mieszkańców danego obszaru stanowią czynniki mogące wpływać realnie na skuteczność aplikowania o środki finansowe (Mrozińska, 2017).

Biorąc pod uwagę operacje sfinansowane z naborów prowadzonych przez LGD „Beskid Gorlicki” zauważa się, że ogólny trend w ramach sekcji PKD jest zachowany. Wnioskodawcy w głównej mierze zamierzali prowadzić działalność gospodarczą w obszarach najbardziej licznych. Pod tym względem dominowała sekcja F - budownictwo. Bardzo często też wnioskowano o dotacje w sekcjach: C - przetwórstwo przemysłowe, $\mathrm{M}$ - działalność profesjonalna, naukowa i techniczna oraz $\mathrm{S}$ - pozostała działalność usługowa. Za niewielkie odstępstwo należy uznać sekcję $\mathrm{H}$ - handel hurtowy i detaliczny, naprawa pojazdów samochodowych, gdzie w licznej grupie podmiotów gospodarki narodowej zarejestrowanych do rejestru REGON towarzyszyło zaledwie pozyskanie czterech dotacji w latach 2017-2019. W sekcji H - transport i gospodarka, odnotowano w latach 2017-2019 systematyczny spadek nowo rejestrowanych podmiotów, a w przypadku analizowanych dotacji na podejmowanie działalności gospodarczej nie odnotowano żadnej operacji w tym obszarze. Należy pamiętać, że obszar dotyczący transportu jest bardzo często ograniczany lub wręcz niemożliwy do sfinansowania z projektów realizowanych ze środków UE. W przypadku operacji realizowanych przez „Europejski Fundusz Rolny na rzecz Rozwoju Obszarów Wiejskich: Europa inwestująca w obszary wiejskie" promowany był jedynie zakup samochodu elektrycznego w kategorii „Wpływ na ochronę środowiska lub przeciwdziałanie zmianom klimatu”.

Projekty inwestycyjne polegające na tworzeniu nowych miejsc pracy, doposażeniu przedsiębiorstw, mają na celu wsparcie różnych aspektów prowadzenia działalności gospodarczej. W ramach przeprowadzanych analiz w pracy zwrócono uwagę na aspekty wsparcia dla osób planujących rozpocząć działalność gospodarczą. Tworzenie korzystnych warunków do zakładania nowych firm ma się przyczynić do przeciwdziałania wysokiej emigracji zarobkowej ludzi młodych, która w przypadku powiatu gorlickiego 
w 2019 roku wyniosła -268 migracji przypadających na 1000 mieszkańców. Ponadto należy pamiętać, że aktywizacja zawodowa i tworzenie miejsc pracy sprzyjają też zwiększeniu potencjału rozwojowego wśród osób wykluczonych lub zagrożonych wykluczeniem z rynku pracy.

Z funduszy unijnych na lata 2014-2020 (np. w ramach działania „LEADER”) realizowane są m.in. projekty, w ramach których osoby fizyczne, rozpoczynające działalność gospodarczą oraz już ją prowadzące, realizują inwestycje umożliwiające utworzenie co najmniej jednego nowego miejsca pracy (Goryńska-Goldmann, Wojcieszak, 2017).

\section{Literatura \\ References}

Brzychcy, K. (2013). Dotacje na działalność gospodarczą jako narzędzie oddziaływania na rynek pracy. Ekonomiczne Problemy Usług, 103, 9-18.

Chmieliński, P. (2015). Koncepcje wsparcia przeobrażeń strukturalnych rolnictwa i obszarów wiejskich w kontekście polityki rozwoju w Unii Europejskiej i w Polsce. W: A. Sikorska (red.), Kierunki przeobrażeń strukturalnych oraz uwarunkowania rozwoju rolnictwa i obszarów wiejskich. Warszawa: Instytut Ekonomiki Rolnictwa i Gospodarki Żywnościowej Państwowy Instytut Badawczy, 9-25.

Goryńska-Goldmann, E., Wojcieszak, M. (2017). Program rozwoju obszarów wiejskich 2014-2020 jako źródło podnoszenia innowacyjności. Roczniki Naukowe Stowarzyszenia Ekonomistów Rolnictwa i Agrobiznesu, 19(1), 44-51.

GUS. (2020, 15 grudnia). Pozyskano z stat.gov.pl.

LGD „Beskid Gorlicki”. (2019). Kryteria wyboru operacji w zakresie podejmowania działalności gospodarczej wraz z procedurq ustalania i zmiany kryteriów. Załącznik nr 1 do Uchwały Zarządu Stowarzyszenia Lokalna Grupa Działania „Beskid Gorlicki” Nr 1/I/2019 z dnia 27.11.2019 r. Pozyskano z http://www.lgdbeskidgorlicki.pl/

LGD „Beskid Gorlicki”. (2020, 7 listopada). Pozyskano z http://www.lgdbeskidgorlicki.pl/

LGD „Beskid Gorlicki”. (2020, 17 listopada). Strategia Rozwoju Lokalnego kierowanego przez społeczność Stowarzyszenia Lokalna Grupa Działania „Beskid Gorlicki”. Załącznik nr 1 do Uchwały Zarządu Stowarzyszenia Lokalna Grupa Działania „Beskid Gorlicki” Nr 1/I/2020 z dnia 31 lipca 2020 r. Pozyskano z http://www.lgdbeskidgorlicki.pl/

LGD „Beskid Gorlicki”. (2020, 4 grudnia). Wyniki ocen wniosków w ramach naborów prowadzonych przez LGD „Beskid Gorlicki” z lat 2017-2019. Pozyskano z http://www.lgdbeskidgorlicki.pl/

Marcysiak, A., Marcysiak, A. (2016). Zakres oddziaływania stanu infrastruktury technicznej na rozwój małych i średnich przedsiębiorstw w wybranych województwach. Zeszyty Naukowe Uniwersytetu Przyrodniczo-Humanistycznego w Siedlcach. Administracja i Zarządzanie, 38, 111-120.

Mrozińska, A. (2017). Skuteczność pozyskiwania środków na realizację projektów unijnych w miastach wojewódzkich w perspektywie 2007-2013. Prace Komisji Geografii Przemysłu Polskiego Towarzystwa Geograficznego, 31(2), 26-38. doi: 10.24917/20801653.312.2

Murzyn, D. (2013). Wykorzystanie funduszy strukturalnych UE w przedsiębiorstwach Małopolski jako czynnik rozwoju gospodarki opartej na wiedzy i innowacji. Prace Komisji Geografii Przemysłu Polskiego Towarzystwa Geograficznego, 21, 253-267.

Pizło, W. (2009). Studium przypadku jako metoda badawcza w naukach ekonomicznych. Roczniki Naukowe Stowarzyszenia Ekonomistów Rolnictwa i Agrobiznesu, 11(5), 246-251.

Powiatowy Urząd Pracy w Gorlicach. (2020, 16 listopada). Rynek Pracy. Bezrobocie rejestrowane w gminach powiatu gorlickiego. Pozyskano z https://gorlice.praca.gov.pl/rynek-pracy

Rozporządzenie Ministra Rolnictwa i Rozwoju Wsi z dnia 24 września 2015 r. w sprawie szczegółowych warunków i trybu przyznawania pomocy finansowej w ramach poddziałania „Wsparcie na wdrażanie operacji w ramach strategii rozwoju lokalnego kierowanego przez społeczność" objętego Programem Rozwoju Obszarów Wiejskich na lata 2014-2020. Dz.U. 2015, poz. 1570, z późn. zm. 
Rozporzqdzenie Parlamentu Europejskiego i Rady (UE) nr 1305/2013 z dnia 17 grudnia 2013 r. $w$ sprawie wsparcia rozwoju obszarów wiejskich przez Europejski Fundusz Rolny na rzecz Rozwoju Obszarów Wiejskich (EFRROW) i uchylające rozporządzenie Rady (WE) $\mathrm{nr}$ 1698/2005. Dz.U. UE L 347/487, poz. 487.

Rozporządzenie Rady Ministrów z dnia 24 grudnia 2007 r. w sprawie Polskiej Klasyfikacji Działalności (PKD). Dz.U. 2007, nr 251 poz. 1885.

Sługocki, W. (2018). Programy Unii Europejskiej skierowane na rozwój obszarów wiejskich i wzrost ich konkurencyjności. Zeszyty Naukowe Organizacja i Zarządzanie. Politechnika Śląska, 129, 547-559.

Szara, K., Majka, A. (2017). Korzyści z wykorzystania funduszy unijnych w gminach Podkarpacia. Nierówności Społeczne a Wzrost Gospodarczy, 49, 384-395.

Urząd Statystyczny w Krakowie. (2019). Statystyczne vademecum samorządowca 2019. Powiat gorlicki. Pozyskano z https://krakow.stat.gov.pl/vademecum/vademecum_malopolskie/ portrety_powiatow/powiat_gorlicki.pdf (dostęp 4.11.2020).

Zioło, Z. (2010). Uwarunkowania kształtowania się procesów transformacji przemysłu i usług. Prace Komisji Geografii Przemysłu Polskiego Towarzystwa Geograficznego, 15, 45-60.

Mateusz Ćwikła, dr inż., Akademia Humanistyczno-Ekonomiczna w Łodzi, Wydział Ekonomii i Zarządzania, absolwent studiów doktoranckich na Wydziale Nauk Społecznych Uniwersytetu Pedagogicznego im. KEN w Krakowie, ukończył studia podyplomowe na Wydziale Prawa Wyższej Szkoły Ekonomii, Prawa i Nauk Medycznych w Kielcach, studia podyplomowe na Wydziale Budownictwa i Architektury, studia magisterskie i licencjackie na Wydziale Matematyczno-Przyrodniczym Uniwersytetu Jana Kochanowskiego w Kielcach oraz studia inżynierskie na Wydziale Budownictwa i Inżynierii Środowiska Politechniki Świętokrzyskiej w Kielcach. Posiada uprawnienia audytora wewnętrznego Systemu Zarządzania Środowiskowego ISO 14001 (DEKRA) oraz Systemu Zarządzania Bezpieczeństwem i Higieną Pracy ISO 45001 (URS). Ukończył kurs Teorii Rozwiązywania Innowacyjnych Zadań i posiada międzynarodowy certyfikat I stopnia TRIZ-MAN. Właściciel firmy konsultingowej, która zajmuje się obsługą instytucji i firm w zakresie przepisów ochrony środowiska.

Mateusz Ćwikła, PhD Eng., University of Humanities and Economics in Lodz, Department of Economics and Management, He graduated from doctoral studies at the Faculty of Social Sciences of the Pedagogical University of Krakow, completed post-graduate studies in the Faculty of Law at the University of Economics, Law and Medical Sciences in Kielce, post-graduate studies at the Faculty of Civil Engineering and Architecture, BA and MA studies in the Faculty of Mathematics and Natural Sciences at the Jan Kochanowski University in Kielce and engineering studies in the Faculty of Civil Engineering and Environmental Engineering at the Kielce University of Technology. He is licensed as an internal auditor of the ISO 14001 Environmental Management System (DEKRA) and the ISO 45001 Occupational Health and Safety Management System (URS). He completed the Theory of Solving Innovative Tasks course and owns international certificate of 1st degree TRIZ-MAN. The owner of a consulting company that provides services to institutions and companies in the field of environmental protection regulations.

ORCID: https://orcid.org/0000-0002-7490-4307

\section{Adres/address:}

Akademia Humanistyczno-Ekonomiczna w Łodzi

Wydział Ekonomii i Zarządzania

ul. Sterlinga 26

90-212 Łódź, Polska

e-mail: mcwikla@ahe.lodz.pl 